\section{Vaid üks eesti kirjandus?}

Kojuigatsus - kauguseigatsus, kahte harusse kasvav puu

Karl Ristikivi

See lugu algab Kalju Lepiku artikli- ja esseekogumiku pealkirjaks tõstetud fraasist „Vaid üks eesti kirjandus”. See on ütlemine, mida kasutati palju eriti 1980.-1990. aastate vahetusel. Koos metafooriga kahte harusse kasvanud puust hakkas see kirjeldama eesti kirjanduse saatust Teise maailmasõja järel.

Lepik jagab selle teema kaheks. Üheks pooleks on mõte, et eesti kirjandus on üks, kirjaniku elukoht ei ole oluline, elagu ta Eestis, Rootsis või mujal. Nii on. Kirjanikud on elanud läbi aegade ikka välismail, kuigi mitte nii tihti kui kunstnikud. Lihtsalt öeldes, keeltpidi kinni olevad kirjanikud vajavad palju enam seda maad, kus keelt kõneldakse, seevastu kunstnikud käivad hoopis enam kokku kunstivoolude, õpetajate ja linnade kaudu. Aga kirjanikud on ka olnud otseselt paguluses juba antiigist peale, kord sunniviisil, kord vabatahtlikult. Paguluses elas Ovidius, paguluses elas Dante, elasid Voltaire, Victor Hugo ja Oscar Wilde... Enamasti ikka poliitilistel, harva muudel põhjustel.

Aga pagulusel ja pagulusel on vahe. Ka eesti kirjanikud elasid paguluses juba XX sajandi algul, kas või Eduard Vilde ja Friedebert Tuglas. Aga nemad avaldasid oma teoseid ikka kodumaal ja Tuglas käis salaja ka ise mitu korda kohal. Võib siis küsida, kas see oli päriselt pagulus, kuigi jah, kodumaal oleks neid tabanud arreteerimine ja vangla? Millal algab pagulus?
Jättes kõrvale paguluse, eksiili jm sõnade ideoloogilised nüansid, saab mu arvates päris pagulus alguse siis, kui saadakse aru, et ei ole enam tagasiteed. Teise maailmasõja põgenikud läksid ju valdavalt ajutiselt ja elasid mitmeid aastaid kohvrite otsas. Enne kui sai selgeks, et pagulus jääb. Ja ka Eestis oodati aastaid valget laeva, kuni saadi aru, et nõukogude võimust ei ole tagasiteed. Aga millal algas pagulaskirjandus? Kas hetkest, kui inimesed said aru tagasitee puudumisest, või siis, kui kirjanikud mõistsid, et nende teostel, nende mõtetel ei ole teed koju? Paradoksaalselt saab kirjanduse pärispagulus alguse varem kui inimeste oma. Ja millal see pagulus lõppes? Kas siis, kui selgus, et inimeste tagasitee on olemas ja jäb? Või siis, kui tagasi hakkasid tulema teosed?

Jättes tsensuuri ja muud keelud praegu kõrvale, tuleb küsida ka seda, mida tähendab teoste tagasitulek. Jah, esimene ja oluline asi oli võimalus neid lugeda. Mäletan isegi, kui istusin päevade kaupa Tartu ülikooli raamatukogus ja lugesin Rootsist saabunud kirjandust, mis laudadele välja pandud (ja mida minu mälu pidi koju ei laenutatud). Ja mäletan ennast pidamas loenguid pagulaskirjandusest Tartus, Viljandis, Vôrus. Ja pisikesi kartoteegikaarte, kuhu kogusin kätte saadud ja ikka katkendlikku infot välismail ilmunud teoste kohta. Mäletan ka oma palju paksu verd tekitanud ettekannet sealsamas ülikooli raamatukogus, kus mul jätkus jultumust öelda keset pagulaskirjanduse ülistust, et see on meile ikka veel võõras.

Ja siin jõuan Lepiku teise mõtte juurde, mida ta oma artiklivalimikus vähemalt kaks korda kordab. Nimelt, et kodueesti ja pagulaskirjandust kirjanduslooliselt ühte liita on võimatu ülesanne. Küsimus ei ole 
kirjanikes ega nende elukohas, füüsilistes teostes kaupluse või raamatukogu riiulitel, vaid kirjandusloos, seostes ja suhetes, mis luuakse tagantjärele. Ja siin seisame kirjanduse kahe haru küsimuse ees. Mis kasvas kahte harusse? Millal kasvas? Kuidas kasvas?

Kui vaadata lähemalt, siis näeme, et sõjajärgse kirjanduse lugu läheb tõepoolest kiiresti kaheks. On kirjandus välismail, ennekõike Rootsis, mida valitsesid rahvuslik ideoloogia ja rahvuslik identiteet, ning on nõukogude kirjandus Eestis, mida valitsesid stalinistlik ideoloogia ja klassikeskne identiteet. Ja suur meri nende vahel. See oli aeg, mil noored Kalju Lepik ja Raimond Kolk kuulutasid Rootsis, et nemad jätkavad nii Betti Alveri kui ka Juhan Sütiste teed ning eitavad võõrast (ja ka ideoloogiliselt punast) sürrealismi ehk Ilmar Laabanit ja tema kaaslasi. Ja see oli aeg, mil Nõukogude Eestis hakati viima ellu V. I. Lenini õpetust selle kohta, et kodanliku ühiskonna kirjandusest tuleks võtta sotsialistliku ühiskonna varasalve üksnes selle nn demokraatlik osa, sedagi vaid vastukaaluks nõukogude kirjandusele. Praktikas teadupärast visati ajaloost minema peaaegu kõik, alates avangardist ja estetismist ning lõpetades Alveriga. Sütiste siiski servapidi jäi. Ja muidugi lendas üle parda pagulaskirjandus.

Aga vaevalt viisteist aastat hiljem hakati rääkima midagi muud, nii siinkui ka sealpool vett. See oli aeg, mil Ain Kaalep, Jaan Kross jt hakkasid taaslooma silda sõjaeelse kirjandusega, nii Alveri kui ka Sütistega. Nii et kodumaine kirjandus kasvatas oma oksa pagulaskirjandusega samale sõjaeelsele tüvele.

Teadupärast oli ka teine liikumine. Noorem põlvkond, olgu Jaan Kaplinski, Andres Ehin, Paul-Eerik Rummo ja teised 1960. aastatel alustajad, leidsid endale kirjanduse, mida tehti paguluses. Sealhulgas nii Lepiku kui ka Laabani, modernismi ja sürrealismi. Ja teisel pool vett kuulutas Lepik aastal 1965, et eesti kultuur on üks ja pagulaskultuur ei ole mingi terviklik nähtus. Tõmmates selle kaudu omapoolse piiri paguluse räige servaideoloogiaga. Paguluse noorem kirjanike põlvkond aga võttis omalt poolt vastu kodueesti noorte mõtted ja võtted. See kõik oli taandumine nii kodumaise kui ka paguluse räuskavatest ideoloogiaservadest. Ideoloogiat ei visatud päriselt minema, aga see suruti tagaplaanile ja ettepoole tõsteti identiteet. Üks eesti kirjandus. Samas, väga tähtis oli kodueesti ja paguluse nooremat põlvkonda ühendav uue aja maailma hõngus, autentsuse igatsus, biitnike revolutsioon, nooruse ja armastuse kuulutus. Kokkuvõttes, kodueesti kirjandusest kadus stalinism ja pagulaskirjandus hakkas minu arusaamist mööda muutuma vaikselt väliseesti kirjanduseks, mida pagulaskirjandusest eristab just ideoloogiast eemaldumine. Muidugi jäid ideoloogilised servad nii siin kui ka seal alles. Aga suund oli selge ja aeg liikus vaatamata kõigele muutuste poole. Kuni ühel hetkel, 1989. aasta mais, saadi kokku Helsingis ja tõmmati joon alla. Siis tõusis ka esile mõte, et eesti kirjandus on kõigele vaatamata üks. Selles lauses kõlas tol ajal lootus ning veidi ka tahe unustada need vastuolud, mis olid olnud. Aga küsimus jäi. Kas saab neid kahte kirjandust kirjandusloos ühte liita? Mu vastus sellele on tegelikult vastusest kõrvale hiilimine. Kas on üldse vaja kokku liita?

Sellega tekkis aga omaette paradoksaalne olukord kirjandusloo jaoks. Kui panna näpp sõjajärgsele ajale, siis seisab paguluse poolel sõjaeelse kirjanduse jätkamine ning kodueesti poolel stalinistlik katkestuskirjandus. Ajaloost vaadates oli see poolsurnult sündinud irdharu, mida Loomingu Stalini-aegse toimetaja August Alle sõnu kasutades võiks iseloomustada kui virtsaniret toimetaja portfellist. Sealjuures polnud sellel pikka iga. Isegi sot- 
sialistlik realism laiemalt kadus kiiresti perifeeriasse. Kui aga panna näpp 1990. aastatele, siis seisab ühel pool kodueesti kirjandus ja teisel pool üha selgemalt pagulaskirjandus oma alguse ja lópuga. Pole mõtet salata, kirjandusloo jaoks jääb igasugune pagulaskirjandus kõrvalharuks. Ja mida pikemaks muutub kirjanduse aeg, seda lühem on selle haru suhteline aeg.

Neis kahes oma alguse ja lõpuga harus on varjatult olemas vastus kirjanduste liitmise kohta. Selleks tuleb minna ajas kaugemale ja kõrvale mööda kirjandusloo radu.

Juba üle sajandi on eesti kirjandusloos tegeletud sellega, et mingil viisil kokku ühendada baltisaksa ja eesti kirjandus. Veel enne Teist maailmasõda võeti eesti kirjanduslugudesse vaid neid baltlasi, kes kirjutasid eesti keeles, ja ainult see, mida nad eesti keeles kirjutasid. Ennekõike nõukogude ajal lisati need, kes kirjutasid saksa keeles, aga mingis mõttes eesti meeles, suhtudes pärismaalastesse positiivselt. Nagu XVIII sajandi esto-/baltofiilsed publitsistid. Ja siis hakkas esimesena vist O. A. Webermann kõnelema maiskondlikust kirjandusest, milles kahte kirjandust ühendab kodumaa, suhe selle maaga, mille kaudu nad ennast mõtestavad. Selles suunas mõtlevad mu arusaamist pidi ka praegused balti kirjanduse uurijad eesotsas Jaan Unduski ja Liina Lukasega. Ühesõnaga, alguses oli ühendajaks keel, siis ideoloogia ja siis maa. Aga pildil on teinegi pool. Üha enam kirjutatakse varasemast kohalikust ladinakeelsest kirjandusest, mis kuulub samuti eesti kirjanduspilti (nagu XVII sajandi juhuluule). Mängu tulevad ka balti päritolu autorid, kelle olulised teosed on hoopis prantsuskeelsed (nagu Barbara Juliane von Krüdener). Lisaks, baltlased ise on arvanud ammu enda hulka rea kirjanikke, kes elasid ja töötasid Saksamaal, kuid väljendasid nn balti eluhoiakut (nagu Siegfried von Vegesack). Ja sama kehtib eesti uurijate kohta. Ühesõnaga, ühendajad on vaikselt hajumas. Taanduvad nii maa kui ka selle maa keel. Eestlastesse suhtumise ideoloogia ei paista olevat üldse oluline. Selle asemele on tõusmas midagi, mis kannab nime balti eluhoiak.

Ja teisalt eestivene kirjandus. Eestivene kirjandus ei huvitanud aastakümneid suurt kedagi. Kui, siis ehk sobiva hingena nõukogudevastases ideoloogilises võtmes (nagu Sergei Dovlatov, kes sattus elama mõne aasta Eestis). Aga umbes kümme aastat tagasi ilmusid areenile uued nimed, ennekõike Andrei Ivanov, kes ise ei taha ennast sugugi rahvuslikult või maiskondlikult identifitseerida, või kui, siis Tallinna kirjanikuna. Ja järsku hakkas eesti kirjandus teda endale tahtma. Ta oli otsekui katalüsaator, mis algatas debatid selle üle, mis on ja kuhu kuulub õieti eestivene kirjandus. Aga andku issand mulle andeks, mulle paistis siis ja paistab ka praegu, et Ivanovi endale himustamise taustal oli lihtne tõsiasi: ta on vaieldamatult väga hea kirjanik. Ideoloogia, elukoht ja keel ei ole olulised.

Niisiis, on olnud keel, ideoloogia ja maa. Aga kord on nad ühendajad ja kord eraldajad. Jäänud on eluhoiak ja kirjanduse tase. (Ideoloogiat ei maksa siiski alahinnata. Kunagi oli Ivanoviga natuke samalaadses seisus Mihhail Veller, auhinnatud autor ja omaaegne Vikerkaare toimetaja. Vellerist on saanud väga konservatiivne, rassismi kalduv ja ka skandaalne tegelane. Kas keegi mäletab veel? Tema tekste refereeritakse Objektiivis...)

Aga kirjanduslugu ei saa piirduda nende piiridega. On veel vähemalt kaks vana teemat.

Üks on rahvaluule, mis kirjanduse lugudes on alati olnud probleemiks. Lahendused on lihtsad. On lugusid, kus see on välja jäetud, ja lugusid, kus sisse võetud. Põhjendusi üldiselt ei tooda. Arvata võib, et need on suulisus, anonüümsus ja 
variatiivsus. Lähemalt vaadates ei ole ükski eriti sobiv rahvaluule väljaarvamiseks. Vanemat poolsuulist kirjandust kõrvale jättes, ka XIX sajandi eesti luule kandis enamasti laulu nime. Ja kirjandusloos on alles peaaegu ainult need luuletused, mis on püsinud elus laulusõnadena. Olgu „Mu isamaa...”, „Kungla rahvas” või „Ööbikule” ehk „Õrn ööbik”. Lähemalt vaadates leiab kogu proosakirjandusest suulise keele jooni üsna palju, kuni selleni, et Oskar Lutsu suurklassika „Kevade” kubiseb suulise keele joontest. Anonüümsus on vanema kirjanduse üldtuntud omadus ja selle variant pseudonüümsus elab priskelt edasi. Kõne alla tuleks ehk variatiivsus, kuid sedagi leiab sadade ja sadade luuletuste eri variantidest ja isegi pikemast proosast.

Kui minna keelele lähemale, siis tõuseb probleemiks ka murdekirjandus. Pikka aega oli see lihtsalt kirjanduskildude sari, kuhu käisid kokku ennekõike lõunaeesti murdeid kasutav luule (Hendrik Adamson, Artur Adson, Raimond Kolk) ja natuke saartemurdelist proosat (Juhan Smuul, Jüri Tuulik). Ja piiril näiteks autorid, kes on kasutanud murret oma teoste otsekõnes (nagu A. H. Tammsaare), või XX sajandi alguse modernistid, kes laenasid lõunaeesti murdemorfoloogia oma põhjaeesti tekstidesse ja/või ihalesid lõunaeesti keelt kirjakeeleks (nagu Friedebert Tuglas). See pilt hakkas murenema hetkel, kui võrokesed ja setod ei leppinud enam oma staatusega. Kui võru murdest sai uusvõru kirjakeel ja kirjanikud hakkasid vaatama oma töid kui omaette lõunaeesti kirjandust. Jah, selle lugu on katkendlik ja fragmentaarne ning kirjanikud ja uurijad on vaielnud, kas see on ühtse eesti kirjanduse osa või omaette kirjandus ning kas rahvaluule kuulub sellesse kirjandusse või mitte (loetagu Mart Velskri sissevaateid ja Kauksi Ülle kirjutisi). Aga lõunaeesti kirjandus on olemas. Veel enam, uuemad keele- ja arheoloogiauurimused kõnelevad ühemõtteliselt, et lõunaeesti keele eelkäija oli esimene, mis eraldus omaette keeleks siis, kui läänemeresoomlased siia maile saabusid. Nii võib öelda, et murdeks paigutab selle üksnes asjaolu, et lõunaeestlased on Eesti riigi alamad...

Ühesõnaga, keelte maailmale lisanduvad murreteks nimetatud allkeeled ja vaikimisi kirjalikule traditsioonile suuline pool.

Ja nüüd võib uuesti küsida. Kas jääda selle juurde, et on vaid üks eesti kirjandus? Mis on see üks eesti kirjandus selles maailmas? Küsimus ei ole demagoogia ega provokatsioon. Kui räägikski mitmest eesti kirjandusest? Kui mitmest, oleneb sellest, kuidas defineerida eestit ja kirjandust. Kodueesti kirjandus, pagulaskirjandus, välismaine eesti kirjandus, eestikeelne, võrukeelne, setokeelne, saksakeelne, venekeelne, kirjalik ja suuline...

Muidugi ei ole need kirjandused võrdsed, mõni on suurem ja mõni pisem. Mõni on kesksem ja mõni servapoolsem. Neil kõigil on ajaloos oma algus ja keskpaik ning mõnel ka lõpp. Puu metafoor nende jaoks ei sobi, looduse juurde jäädes moodustavad nad pigem hargnevate ja põimuvate väänkasvude kogumi. Ma eelistan tulla loodusest inimese juurde: parem metafoor on perekond. Selles on keelesugulased ja maasugulased. Mõni on lähem ja mõni kaugem sugulane. Mõni vaid hõimlane, kes abielu kaudu tulnud. Mõni abielus ja mõni vabas kooselus. Mõni ema ja mõni laps. Eesti kirjandus kui kärgpere.

TIIT HENNOSTE 